\title{
OD STATYSTYKI DO EWALUACJI BIBLIOTEK
}

\author{
Teresa Szmigielska \\ Biblioteka Sejmowa
}

Biblioteki naukowe, ewaluacja, wskaźniki funkcjonalności

Od dawna biblioteki podawały do publicznej wiadomości dane o wielkości swoich zbiorów. Zasobność biblioteki przekładała się bowiem na jej ocenę - im większe zbiory, tym bogatsza, lepsza biblioteka. W połowie dwudziestego wieku zbiory największych bibliotek osiągnęły takie rozmiary, że zarządzanie nimi przysparzało coraz więcej problemów. Dobrą biblioteką okazywała się ta, która w krótkim czasie dostarczała użytkownikowi właściwe publikacje, niekoniecznie pochodzące z własnych zbiorów. Wzrost kosztów utrzymania spowodował, że bibliotekarze oraz wspierający ich specjaliści z innych dziedzin szukali metod lepszego zarządzania. Śledzenie rozwoju badań statystycznych w bibliotekach pozwala stwierdzić, że jest to proces ciągły, w którym sumuja się doświadczenia dotyczące statystycznego opisu biblioteki. Ewaluacja - systematyczne, jawne działania polegające na zbieraniu i analizowaniu informacji, której wyniki podawane są do publicznej wiadomości, a wnioski płynące z badań są popularyzowane, jest charakterystyczna dla społeczeństw demokratycznych.

Literatura przedmiotu pokazuje, jak na podstawie danych statystycznych tworzono i opisywano kolejne wskaźniki funkcjonalności. Wskaźniki dawały możliwość analizy zjawisk dynamicznych, ze szczególną uwagą oceniały efektywność kosztową biblioteki akademickiej. Na początku zbierano dane dla jednej uczelni, później porównywano je z danymi bibliotek różnych szkół wyższych. Różnorodność zbieranych danych statystycznych oraz brak ujednoliconych definicji wskaźników funkcjonalności stały się w dwudziestym wieku impulsem do prac nad stworzeniem jednakowych metod oceny pracy biblioteki, pozwalajacych na porównywanie i tworzenie rankingów. Konsekwencją tych działań było powstawanie ujednoliconych wzorców oceny, z dokładnie opisanymi metodami badawczymi zwanymi zaleceniami, normami lub standardami.

W latach 90. XX w. zainteresowano się unormowaniem badań dotyczących jakości. Do ujednoliconego i dokładnego badania jakości pracy biblioteki zaproponowano stosowanie normy ISO 11620: 1998 Information and Documentation - Library Performance Indicators ${ }^{1}$. Opublikowano także zalecenia dla

1 ISO 11620:1998 Information and documentation. Library performance indicators; wersja polska PN-ISO 11620:2006 Informacja i dokumentacja. Wskaźniki funkcjonalności bibliotek. 
bibliotek akademickich, opracowane przez IFLA². Biblioteki otrzymały narzędzie stworzone z dobrze opisanych i wypróbowanych wskaźników, które mogą wykorzystywać do ewaluacji wybranych procesów bibliotecznych, ich ocen i porównań.

Jak wynika z analizy źródeł bibliograficznych, wartościowa literatura dotycząca problematyki statystyki i ewaluacji bibliotek akademickich jest obszerna. Na początku dwudziestego wieku tematyka ta dominowała w literaturze amerykańskiej, od lat siedemdziesiątych pojawia się również w Europie. Ilustruje to analiza bibliografii załącznikowych do norm ISO $^{3}$ oraz dokumentów IFLA ${ }^{4}$ dotyczacych publikacji omówionych w niniejszym artykule. Informacje o dokumentach będących w posiadaniu polskich bibliotek zaczerpnięto także z Bibliografii Analitycznej Bibliotekoznawstwa i Informacji Naukowej5. Przyjęto, że te same dokumenty przytoczone w różnych zestawieniach stanowiły podstawę do tworzenia zasad ewaluacji wykorzystującej dane statystyczne.

W artykule przedstawiono zmiany, jakim podlegaly metody oceny pracy biblioteki. Materiał uporządkowany został w taki sposób, aby pokazać sumowanie się doświadczeń i związki między badaniami prowadzonymi przez bibliotekarzy różnych krajów.

Na początku przedstawiono najstarszą literaturę światową dotyczącą zastosowania statystyki w ocenie bibliotek, prace zainicjowane przezAdriano Balbiego i Jamesa Thayera Geroulda. W dalszej części określono uwarunkowania historyczne, społeczne i technologiczne, które stały się impulsem do intensywnych działań usprawniających pracę biblioteki. Najważniejszym powodem okazał się obserwowany w latach 40. XX w. niespotykany wcześniej rozrost księgozbiorów bibliotek największych wyższych uczelni. Jednocześnie skutki drugiej wojny światowej spowodowały ograniczenie środków finansowych i personelu bibliotek. Z powyższych powodów część pracy bibliotekarzy, polegająca na udzielaniu informacji, musiała zostać sprawniej zorganizowana. Zainteresowa-

\footnotetext{
${ }^{2}$ Poll R., Boekhorst P.: Measuring Quality; Performance Measurement in Libraries. Munichen, K. G. Saur 1996, seria: IFLA Publications, nr 76; Poll R., Boekhorst P.: Mierzenie jakości: międzynarodowe zalecenia do pomiaru wykonania zadań w bibliotekach akademickich. Tł. Bolesław Rek. Bibliothecalia Wratislaviensia 2004, nr 7, s. 16; Poll R., Boekhorst P.: Measuring Quality. Performance Measurement in Libraries. Wyd. 2 zm., Munich, K. G. Saur 2007, seria: IFLA Publications, nr 127.

${ }^{3}$ ISO 11620:1998 op. cit., oraz ISO 11620:2008 Information and documentation. Library performance indicators.

${ }^{4}$ Poll R., Boekhorst P.: Measuring Quality. Op. cit; także: IFLANET. Statistics and Evaluation Section. [online]. [dostęp: 12 maja 2008]. Dostępny w World Wide Web: <http:// www.ifla.org/VII/s22/statlikks-related.htm>; ISO 11620:2008 op.cit.; pierwsze wydanie ISO 11620:1998; PN-ISO 11620:2006 op. cit., polskie wydanie nie zawiera bibliografii; Poll R.: Statistics and Evaluation Section, useful links - related to library evaluation. Bibliography Impact and Outcome of Libraries. [online]. [dostęp: 19 stycznia 2008]. Dostępny w World Wide Web: <http://www.ifla.org/ VII/s22/index.htm>, także z projektu BIX lub bezpośrednio ze strony Biblioteki Uniwersytetu Munster. [online]. Dostępny w World Wide Web: <http:// www.ulb.uni-muenster.de/projekte/outcome/downloads/bibliography-impact+outcome.pdf>; [online]. Dostępny w World Wide Web:< http://www.ifla.org/VII/s22/statlinks-related.htm>

${ }^{5}$ Bibliografia Analityczna Bibliotekoznawstwa i Informacji Naukowej. [online]. [dostęp: 2.01.2007]. Dostępny w World Wide Web: <http://mak.bn.org.pl/cgi-bin/makwww.exe? BM=15>
} 
nia badawcze bibliotekarzy skupiły się na doskonaleniu katalogów jako podstawowych źródeł informacji. Jednocześnie przeprowadzano analizę i weryfikowano wykorzystanie zbiorów bibliotecznych. Badania związane z usprawnieniami wybranych aspektów pracy biblioteki doprowadziły do ewaluacji rozumianej jako ciągła kontrola jakości pracy, wspomagająca proces podejmowania decyzji w zarządzaniu. W dalszej części opisane są pojawiające się w literaturze przedmiotu prace przedstawiające zestawy wskaźników, nazywane „zestawami narzędzi" do oceny różnych rodzajów bibliotek, oraz procedury zmierzające do zwiększania efektywności kosztowej bibliotek jako podstawy do właściwej alokacji środków finansowych. W końcowej części artykułu przedstawiono rozwój światowych badań ewaluacyjnych oraz zastosowanie norm do pomiaru jakości pracy bibliotek. Ograniczona objętość artykułu nie pozwoliła na omówienie polskiej literatury przedmiotu.

\section{Najstarsza literatura światowa dotycząca statystyki bibliotecznej}

W pierwszej połowie XIX W. powstało dzieło nieznane polskiej literaturze przedmiotu ${ }^{6}, \mathrm{tj}$. Statistical essay of the libraries of Vienna and the World. Przedstawiało ono w krytyczny sposób dotychczasowe badania wielkości zbiorów bibliotecznych, dawało podstawy do tworzenia standardów oceny wielkości biblioteki. Jego autor, Adriano Balbi ${ }^{7}$, interesował się także jakością statystyki bibliotecznej. Pisał o konieczności wyznaczenia wskaźników do obliczania w jednolity sposób wielkości zbiorów bibliotecznych ${ }^{8}$.

Praca Balbiego posłużyła za wzór badaczom w XX w. W Stanach Zjednoczonych ${ }^{9}$, w pracy pt. Public Libraries in the United States of America, w rozdziale Library Reports and Statistics mówi się o Balbim jako wybitnym specjaliście, który stworzył podwaliny pod statystykę biblioteczna.

Następne godne odnotowania są prace Jamesa Thayera Geroulda, również nieobecne w polskiej literaturze przedmiotu. Gerould był w początku XX w. bibliotekarzem w Bibliotece Uniwersytetu w Minesocie, a od 1920 r. pracował w Bibliotece Uniwersytetu w Princeton. Przez ten czas, a również kiedy był na emeryturze, aż do 1938 r. poświęcał się zbieraniu i publikowaniu danych statystycznych o bibliotekach.

W wystapieniu w 1906 r., na zebraniu American Library Asociacion, Gerould podsumował dotychczasowy dorobek statystyki dla bibliotek publicznych oraz przedstawił możliwe metody zastosowania podobnych wzorów w bibliote-

${ }^{6}$ Ukazał się tylko jeden artykuł: Żbikowska-Migoń A.: Karl Heinrich Frömmichen (17361783 ) and Adrian Balbi (1782-1848). The pioneers of biblio- and scientometrics. „Scientometrics" 2001, vol. 52, nr 2, s. 225-233.

${ }^{7}$ Adriano Balbi ur. w Wenecji w 1782 r. zmarł w 1848 r.

${ }^{8}$ Balbi A.: Essai Statistique sur les Bibliotheques de Vienne. Vienne, Frederic Volke 1835; wyd. w jęz. ang.: Statistical Essay of the Libraries of Vienna and the World. Jefferson, North Carolina, McFarland 1986, przeł. Larry Barr i Janet L. Barr; obszerne infomacje [w:] The Gerould Statistics. Chapter One, s.1. [online]. [dostęp: 15.01.2008]. Dostępny w World Wide Web: <http://fisher.lib.virginia.edu /libsites/ gerould/tgsbib.html>

${ }^{9} \mathrm{U}$. S. Bureau of Education: Public Libraries in the United States of America. Washington, Government Printing Office, 1876. [online]. [dostęp: 15.01.2008]. Dostępny w World Wide Web: <http://fisher.lib.virginia.edu/libsites/gerould/ tgsartcl. html> 
kach akademickich ${ }^{10}$.W 1906 r. sformułował pytania, które zaważyły na tworzeniu bibliotecznych standardów amerykańskich, a później i światowych ${ }^{11}$. Tematy przedstawione przez Geroulda miały być zaczynem zbierania danych z amerykańskich bibliotek akademickich, a następnie prób tworzenia zestawów opisanych językiem statystyki. Bibliotekarze mieli świadomość, że bez dobrze skonstruowanych formularzy statystycznych, obejmujących istotne pola działalności biblioteki, nie będzie można kontynuować badań służących poprawieniu jakości działania biblioteki akademickiej ${ }^{12}$.

Statystyka Geroulda była wydawana jako rocznik i ukazywała się w latach 1907-1920 oraz 1938/39. Kontynuacja od 1939/1940 do 1961/1962 r. została wydana przez The Association of Research Libraries $(A R L)^{13}$. Wydanie pełne ukazało się w latach osiemdziesiątych XX w. z uzupełnieniami za okres 1992$1996^{14}$. Obok kompilacji wydawanych drukiem, w użytku bibliotekarzy w Stanach Zjednoczonych znajdowały się egzemplarze powielane z odręcznymi notatkami, poprawkami, zaopatrzone w uwagi co do sposobu obliczania wyników. Ostatecznie dane zarejestrowane od 1908 do $1988 \mathrm{r}$. znalazły się na stronach ACRL jako wydanie internetowe w $1998^{15}$. Obecnie na internetowej stronie stowarzyszenia ALA można przeglądać, corocznie uzupełniane, dane statystyczne ok. 120 bibliotek akademickich ${ }^{16}$.

Powszechne w Stanach Zjednoczonych zainteresowanie statystyką, dostęp do wieloletnich, kopiowanych i rozpowszechnianych zestawień dla poszczególnych uniwersytetów, a w końcu kompilacje wydawane za lata 1907-1963 doprowadziły do praktycznego udoskonalenia zarządzania bibliotekami wykorzystującego ewaluację. Podczas prac nad porządkowaniem danych statystycznych bibliotekarze prowadzili ożywione dyskusje nad różnorodnymi tematami związanymi ze statystyką biblioteczną i wykorzystaniem jej do usprawnienia zarządzania jakościa pracy.

${ }^{10}$ Gerould J. T.: A Plan for the Compilation of Comparative University and College Library Statistics. "The Library Journal” 1906, s. 761-763. [online]. [dostęp: 16.01.2008]. Dostępny w World Wide Web: <http://fisher.lib.virginia.edu/ libsites/gerould/tgsartcl.html>

11 Standards for Libraries in Higher Education. The Association of College and Research Libraries 2004. [online]. [dostęp: 3.09.2009]. Dostępny w World Wide Web: <http:/ /www.ala.org/ala/mgrps/divs/acrl/standards/standardslibraries.cfm>

${ }^{12}$ Gerould J. T.: A plan for the compilation of comparative university and college library statistics. „The Library Journal” s. 761-763. [online]. [dostęp: 16.01.2008]. Dostępny w World Wide Web: <http://fisher.lib.virginia.edu/libsites/gerould/tgsartcl.html>

${ }^{13}$ Kendon S.: Introduction, ARL Statistics, 1983-1984. Washington, Association of Research Libraries 1985, s. 4-7; oraz tego samego autora: ARL Statistics, 1992-1996: A Guide to the Machine-Readable Version of the ARL Statistics. Washington, Association of Research Libraries 1996. [online]. [dostęp: 15.02.2008]. Dostępny w World Wide Web: <http://viva.lib.virginia.edu/socsci/arl/1994/96doc.html>

${ }^{14}$ Kendon S., Molyneux R.: Research Library Statistics, 1907/1908 Through 1987/1988, A Guide to the Machine-Readable Version of the Gerould and ARL Statistics. Washington, Association of Research Libraries, 1990.

${ }^{15}$ Molyneux R. E.: The Gerould Statistics, 1907/1908-1961/1962, second edition, 1998, An historical compilation of data from academic libraries in the United States and Canada. [online]. [dostęp 15.02.2008]. Dostępny w World Wide Web: <http://fisher.lib.virginia.edu/ libsites/gerould/index.htm|\#toc>

${ }^{16}$ American Library Association. [online]. [dostęp: 14.02.2010]. Dostępny w World Wide Web: <http://www.ala.org/ala/research/librarystats/academic/index.cfm> 
Obecnie do oceny biblioteki, także przez komisje akredytacyjne, wykorzystuje się nie tylko wskaźniki funkcjonalności, ale przede wszystkim ocenę opisowa ${ }^{17}$ zbliżoną do zestawu pytań stworzonych w 1906 r. przez J. T. Geroulda ${ }^{18}$. Do przedstawionej statystyki odnoszą się badania jakości i efektywności pracy bibliotek akademickich prowadzone współcześnie przez ARL ${ }^{19}$.

\section{Tematy badań prowadzonych przez bibliotekarzy od początku XX w.}

W gospodarce rynkowej wszystkie podmioty podlegaja prawom rynku. Biblioteki uczelni prywatnych w Stanach Zjednoczonych musiały ubiegać się o fundusze na działalność, rywalizować o uzyskanie grantów i inne formy dotacji pozarządowych. Zarządy bibliotek amerykańskich były zmuszone do uzasadniania potrzeby wsparcia finansowego oraz do rozliczania się z otrzymanych sum. Literatura przedmiotu dowodzi, że bibliotekarze bibliotek akademickich w Stanach Zjednoczonych kładli szczególny nacisk na gromadzenie i wykorzystywanie danych statystycznych. Statystyka nie była celem, lecz narzędziem gwarantującym efektywne zarządzanie zbiorami, personelem, obsługa czytelnika. Wysoka jakość organizacji biblioteki przekładała się na widoczną w statystyce sprawność w uzupełnianiu i wykorzystaniu zbiorów, właściwą proporcję wydatków, rosnącą liczbę wypożyczeń. Zestawienia statystyczne, wymieniane między bibliotekami i uzupełniane komentarzami, utworzyły pierwszą bazę umożliwiającą ewaluację największych bibliotek akademickich w Stanach Zjednoczonych. Stały się podstawą do opracowania amerykańskiego modelu oceny bibliotek akademickich. Gwałtowny wzrost liczby gromadzonych publika$\mathrm{cji}^{20}$ oraz występujące, szczególnie w czasie drugiej wojny światowej, trudności w zdobywaniu środków na prowadzenie bibliotek, przyczyniły się do zweryfikowania dotychczasowych zasad gromadzenia informacji służących do szacowania wyników pracy biblioteki. Badanie danych wejścia (inputs - zbiory, pracownicy, finanse) uzupełniono badaniami danych wyjścia (outputs - liczba wypożyczeń, liczba czytelników). W wydanym w 2004 r. Standardzie ACRL nie ocenia się danych ilościowych inputs i outputs, lecz wkład biblioteki w proces dydaktyczny uczelni oraz przygotowanie studenta do samodzielnych poszukiwań naukowych i kształcenia ustawicznego.

Tematyka publikacji z lat czterdziestych ubieglego wieku dotyczyła planów rozwoju bibliotek naukowych. Planując, zajmowano się głównie kosztami, usprawnieniem informacji i wykorzystaniem zbiorów.

Równolegle z pracami bibliotekarzy indywidualnych, organizacje normalizacyjne finalizowały prace nad ujednoliceniem zasad międzynarodowej statystyki

${ }^{17}$ Gerould J. T.: A plan..., op. cit.

${ }^{18}$ Ibidem.

${ }^{19}$ Kyrillidou M.: Research library trends: ARL statistics. „Journal of Academic Librarianship" 2000, nr 6, s. 427-436; w wersji elektronicznej jako preprint Association of Research Libraries, Washington, DC 2002. [online]. [dostęp: 12.08.2009]. Dostępny w World Wide Web: <http://www.arl.org/bm doc/jal99.>

${ }^{20}$ Biblioteka Uniwersytetu Oksfordzkiego w latach czterdziestych osiagnęła $12 \mathrm{mln}$ pozycji; szacunki dalszego rozwoju mówiły o wzrostach w ciągu dwudziestu-trzydziestu najbliższych lat do kilkudziesięciu milionów zbiorów i o potrzebie zatrudnienia kilkuset osób w każdym dziale biblioteki. 
bibliotecznej21. Tworzono i opisywano użycie wskaźników funkcjonalności. $W$ drugiej połowie XX w. bibliotekarze zajęli się ujednoliceniem nazw oraz normalizacją zasad: zbierania, obliczania i publikowania danych, co zaowocowało wydaniem szeregu wspomnianych norm, standardów i zaleceń.

\section{Koszty}

Zagadnienia związane z kosztami biblioteki były od początku XX w. przedmiotem publikacji amerykańskich bibliotekarzy 22 . W latach trzydziestych prowadzono badania porównawcze kosztów różnych uczelni. Doświadczenia na ten temat przedstawił Fremont Rider ${ }^{23}$, pracownik Biblioteki Uniwersytetu w Yale, który już w latach trzydziestych pisał artykuły o zmniejszaniu kosztów w bibliotece. Analiza kosztów miała według Ridera podstawowe znaczenie w przygotowaniu planów finansowych, które są głównym elementem w negocjacjach z kierownictwem uczelni. Podobnego zdania są D. W. Bryant i B. S. Kaiser, którzy twierdza, że właściwa alokacja kosztów jest jednym z najważniejszych i najtrudniejszych problemów oceny jakości zarządzania biblioteka. Każde badanie rodzi obawy bibliotekarzy, że w jego wyniku nastąpią nadmierne i nieuzasadnione ograniczenia finansowania ${ }^{24}$.

Rider ${ }^{25}$ szczególnie interesował się obniżką kosztów zakupów, magazynowania, współpracy międzybibliotecznej, a także kosztów katalogowania. W bibliotece, w której był zatrudniony, zbiory liczyły niemal dwanaście milionów woluminów. Liczba pracowników bardzo szybko rosła. Rider widział możliwość podołania wyzwaniom poprzez rozwój współpracy regionalnej i specjalizacji bibliotek, wypożyczenia międzybiblioteczne, racjonalizację kolekcji oraz zastosowanie mikrofilmów i mikrofisz. Wszystkie przedstawiane wcześniej tematy i pomysły znalazły się w jego publikacji z 1944 r. ${ }^{26}$. O przyszłości bibliotekarstwa naukowego pisał także wieloletni członek kierownictwa Biblioteki Kongresu, Verner W. Clapp ${ }^{27}$.

${ }^{21}$ Były one prowadzone w ramach wspólnych prac IFLA oraz ISO. Obie te organizacje w 1966 r. wydały raport końcowy: The international standardization of library statistics: a progress report $=$ La normalisation internationale des statistiques relatives aux bibliotheques: etat des travaux, Report of the IFLA/ISO conferences. Paris 1967, Hague 1966, London 1968.

${ }^{22}$ Austen W.: Efficiency in College and University Library Work. „Library Journal” 1911, nr 86, s. 566-569; Williamson C. C.: Training for Library Service, A Report Prepared for the Carnegie Corporation of New York. New York, Updike, Merrymount Press, 1923

${ }^{23}$ Rider F.: Library Cost Accounting. „The Library Quarterly” 1936, t. 6, nr 4, s. 331-381; Rider $F .:$ The scholar and the future of the research library. A problem and its solution. New York, Hadham Press, 1944.

${ }^{24}$ Bryant D. W., Kaiser, B. S.: University Library Position Classification and Compensation Plan. „Library Quarterly” 1947, nr 17, s. 1-17; Position Classification and Salary Administration in Libraries. Chicago, American Library Association, 1951

${ }^{25}$ Steele C.: No easy rider? The scholar and the future of the research library. By Fremont Rider: a review article. [online]. [dostęp: 10.02.2007]. Dostępny w World Wide Web: $<$ http://dspace.anu.edu.au/bitstream/1885/43178/1/Fremont_Rider_article.doc>; Rider jest znanym i cenionym autorem $w$ Stanach Zjednoczonych, w Internecie znajdują się przedmiotowo-podmiotowe zestawienia bibliograficzne dotyczące jego osoby.

${ }^{26}$ Rider F.: The scholar and the future of the research library. A problem and its solution. New York: Hadham Press, 1944.

${ }^{27}$ Clapp V. W.: The Future of the Research Library. University of Illinois Press, Urbana, 1964. 
Zarządzanie i kontrola wzrostu zasobów biblioteki budziły szczególne zainteresowanie bibliotekarzy zarządzających największymi bibliotekami akademic$k^{k i m i}{ }^{28}$. Bezpośrednio po drugiej wojnie światowej, w 1946 r., powstał artykuł Roberta B. Downsa ${ }^{29}$, który dotyczył konieczności prowadzenia dalszych prac nad unifikacją statystyki w zrzeszeniach bibliotek. Późniejsza jego praca podsumowuje sto lat doświadczeń (od 1876 do 1976 r.) w nadzorowaniu rozrastajacych się bibliotek naukowych ${ }^{30}$. O wzroście zbiorów, kosztach i związanej z nimi jakości pracy biblioteki akademickiej pisał także George Piternick ${ }^{31}$.

$Z$ badań wynika, że na jakość pracy biblioteki wpływają również takie czynniki jak podział rynku pracy oraz mobilność bibliotekarzy. Kondycja zawodu bibliotekarskiego, w tym uposażenie pracowników, możliwość kształcenia oraz mobilność zawodowa znalazły się w kręgu zainteresowań Thomasa A. Childersa oraz Nancy A. van House ${ }^{32}$. Ich artykuł zawiera wyniki badań dotyczących segmentacji rynku pracy i wypływających z tego ograniczeń w uposażeniu bibliotekarzy. Podstawą do analizy był wcześniejszy o kilka lat przegląd członków ALA. $W$ analizie wzięto pod uwagę: białych, posiadających stopień magistra, zatrudnionych $w$ pełnym wymiarze godzin $w$ różnych typach bibliotek, $w$ tym $w$ placówkach szkół wyższych posiadających uprawienia do nadawania stopnia magistra. Bibliotekarze w porównaniu z innymi zawodami mieli niższe uposażenia. Wysokość pensji zależała od wielkości biblioteki oraz płci, natomiast zmiana miejsca pracy zdarzała się rzadko. Bibliotekarze awansowali jedynie wewnątrz macierzystej instytucji.

Inna praca, dotycząca kosztów, to artykuł W. F. Lancastera ${ }^{33}$, w którym autor traktuje koszty jako istotny problem w zarządzaniu biblioteką publiczną. Lancaster daje w nim praktyczne wskazówki, jak podejmować optymalne decyzje. $\mathrm{Na}$ przykład, przy określaniu kosztów zakupu dokumentów należy z góry oszacować również wysokość sumy, jaką pochłonie ich opracowanie i gromadzenie. Stwierdził on, że przy tańszych, lecz gorszej jakości pomocniczych materiałach bibliotecznych, naraża się odbiorców na stratę czasu, a ogólna ocena pracy biblioteki obniża się. Ponadto, obniżenie nakładów na komunikowanie się z potencjalnymi i faktycznymi czytelnikami zmniejsza satysfakcję klientów. Trzeba też brać pod uwagę to, jakie są koszty społeczne wynikające z braku rzetelnych, wyczerpujących i podawanych na czas informacji. Szczególną uwagę zwracał

${ }^{28}$ Dunn O. C., Seibert W. F., Scheuneman, J. A.: The Past and Likely Future of 58 Research Libraries, 1951-1980: A Statistical Study of Growth and Change. West Layfayette, Indiana, 1965. s. 3-69.

${ }^{29}$ Downs R. B.: Uniform Statistics for Library Holdings. „Library Quarterly” 1946, nr 16,

${ }^{30}$ Downs R. B.: The growth of research collections. „Library Trends” 1976, American Library History: 1876-1976, nr 25, s. 55-80. [online]. [Dostęp 4.09.2009]. Dostępny w World Wide Web: <http://www.ideals. uiuc.edu/bitstream/ handle/2142/6910/librarytrendsv25i1e opt.pdf? sequence $=1>$

${ }_{31}$ Piternick G.: Library growth and academic quality. „College and Research Libraries" 1963, nr 24, s. 223-229.

${ }^{32}$ Childers T.A., Van House N. A.: Labor Market Segmentation and Librarian Salaries. "Library Quarterly" 1987, nr 2, s. 171-89.

${ }^{33}$ Lancaster W. F.: Evaluation as a management tool. „Public Library” 1990, nr 5 , s. 289-294. 
Lancaster na stosunek kosztów do uzyskanych efektów. Podał też przykłady praktycznych rozwiązań, na przykład, jeżeli 30 tytułów jest w stanie zaspokoić $70 \%$ zapotrzebowań użytkowników, to w celu uzyskania 95\% realizacji zapotrzebowań należy zakupić około 500 tytułów. Autor uważał, że w omawianym przykładzie podjęcie próby maksymalnej efektywności byłoby nieopłacalne.

Cele biblioteki nie są stałe, zmieniają się między innymi pod wpływem badań jakości pracy biblioteki a wyznaczenie nowego celu stymuluje dalsze pomiary i wykorzystanie nowych wskaźników funkcjonalności. Badacz amerykański Richard Stephen ${ }^{34}$ przedstawił wskaźniki funkcjonalności pozwalające na określenie relacji między celami a efektywnością działania. Uznał, że są one potrzebne zarówno bibliotekom, jak też ich instytucjom macierzystym. Wskaźniki funkcjonalności mogą być stosowane do oceny instytucji i porównań między bibliotekami. Autor wskazał na najbardziej, według niego, przydatne wskaźniki: relację między celami biblioteki a celami instytucji nadrzędnej, stosunek osiągniętych wyników do założonych celów, efektywność działań, oszczędność, wydajność. Wskaźniki, poza łatwością ich uzyskania, powinny być określone według norm i wykazywać cechy powtarzalności, pozwalające na dokonywanie pomiarów między podobnymi bibliotekami. Ważne jest, aby mierzyły jakość usług i trafność udzielanych informacji. Autor sformułował tezę, że wskaźniki wykonania zadań są zbyt rzadko obliczane i stosowane, ponieważ kadra zarządzająca nie docenia ich wartości. Do artykułu dołączono wskaźniki wykonania zadań proponowane do wykorzystania.

\section{Wykorzystanie zbiorów}

Bibliotekarze dążyli do budowania kolekcji w taki sposób, aby w jak największym stopniu zaspokajała zapotrzebowanie użytkowników, jednocześnie chcieli ograniczyć liczbę dokumentów, które były niedostatecznie wykorzystane. Niemniej ważnym czynnikiem skłaniającym do podjęcia badań była, omawiana w poprzednim punkcie, konieczność ograniczania wydatków. W Biuletynie Amerykańskiego Stowarzyszenia Bibliotekarzy ukazały się badania przeprowadzone w latach pięćdziesiątych ubieglego wieku w Bibliotece Naukowej MIT (Massachusetts Institute of Technology) przez Philipa Morse'a, dyrektora biblioteki, i jego współpracowników. Nazwano je „Operacyjnymi badaniami biblioteki”. Polegały one na badaniu intensywności obiegu dokumentów zarejestrowanych w inwentarzach biblioteki i udostępnionych użytkownikom. Dokumenty do badań dobierano na podstawie próby losowej ${ }^{35}$.

Robert Orr ${ }^{36}$, bibliotekarz z biblioteki w Coldwater w USA, zadał pytanie dotyczące ocenienia na podstawie badań, czy dana biblioteka jest dobra, czy możemy pozytywnie ocenić bibliotekę według wielkości zbioru, czy według jakości obsługi ${ }^{37}$. Opisał przypadek biblioteki, która posiada wspaniały, jedyny na

\footnotetext{
${ }^{34}$ Stephen R.: Library use of performance indicators. „Library Review” 1992, nr 6, s. 22-36.

${ }^{35}$ Bush G. C., Galliher H. P., \& Morse P. M.: Attendance and Use of the Science Library at MIT. „American Documentation” 1956, s. 87-109.

${ }^{36}$ Orr R.: Measuring the goodness of library services: a general framework for considering. „Journal of Dokumentation”1973, nr 29, s. 315-332.

${ }^{37}$ Mówią o nim także Baker S. L., Lancaster F. W.: The measurement and evaluation of library services. Wyd. 2, Arlington, Information Resources Press 1901, [1 wyd. 1977].
} 
świecie zbiór perskich modlitewników. Teoretycznie jest to doskonała kolekcja, ale jakość biblioteki, to według Orra zdolność do zaspokajania potrzeb czytelników. Jeśli biblioteka z takim zbiorem znajdzie się w Ameryce lub na słabo zaludnionych stepach Azji, to jej zbiór nie zostanie właściwie wykorzystany.

Edward Evans zajmował się badaniem jakości i efektywności pracy bibliotek medycznych ${ }^{38}$. Było to jedno z pierwszych ankietowych badań dla wybranej grupy bibliotek akademickich, wykonane w końcu lat sześćdziesiątych ${ }^{39}$. Brano przy tym pod uwagę specyficzne wymagania wobec usług świadczonych przez biblioteki medyczne. Sformułowano sześć najważniejszych wskaźników ewaluacji biblioteki: dostępność, koszty, zadowolenie użytkowników, czas reakcji, korzyści dla użytkowników, wykorzystanie. W artykule znajduje się konkluzja na temat błędnych ocen wyników badań spowodowanych niejasnością celów oceny działalności biblioteki.

Powstały również prace dotyczące badania zbiorów jednej biblioteki akademickiej, w tym przypadku Biblioteki Uniwersyteckiej w Pittsburghu. Do badań wykorzystania zasobów bibliotecznych T. J. Galvin i A. Kent ${ }^{40}$ zastosowali różne metody: kwestionariusz ankiety, wywiad, obserwację obiegu dokumentów. Podobną problematyką zajmował się też J.G. Schad ${ }^{41}$. George S. Bonn ${ }^{42}$, konsultant w zakresie wykorzystania sprawozdań bibliotecznych, znawca bibliotek w Stanach Zjednoczonych, Indiach, Japonii i Turcji wykorzystywał wiedzę do propagowania wykorzystania list eksperckich w ocenie księgozbiorów bibliotek akademickich.

Prekursorskie badania dotyczące tworzenia matematycznego modelu wykorzystania zbiorów wykonalo dwóch specjalistów - Herman H. Fussler, bibliotekarz i ekonomista, przez ponad trzydzieści lat dyrektor Biblioteki Uniwersytetu w Chicago i Julian L. Simon, ekonomista badajacy efekty ekonomiczne w populacjach znajdujących się w toku zmian. Praca Patterns in the Use of Books in Large Research Libraries ${ }^{43}$ zawierała relacje z badania przeprowadzonego przez każdego z nich oddzielnie, na różnych zbiorach bibliotecznych. Obaj stosowali metody prób losowych, budując modele matematyczne poprawności wyszukiwania książek na półce. Sprawdzali też, po jakim czasie dostępne są dla czytelnika pozycje wybrane losowo z inwentarza.

${ }^{38}$ Evans E., Borko H., Ferguson P.: Review of criteria used to measure library effectiveness. „Bulletin of the Medical Library Association” 1972, nr 1, s. 102-110. [online]. [dostęp: 06.2007]. Dostępny w World Wide Web: <http://www.pubmedcentral.nih.gov/articlerender.fcgi?artid=198632>; Evans A., Mirsky P. S., Victoria M. J. de: Evaluation of a library program in a Carnegie model area health education center. „Bulletin Med. Library Assocation” 1978, nr 66, s. $190-199$.

${ }^{39}$ Nie znaleziono wcześniejszych przykładów grupowych badań dla bibliotek naukowych.

${ }^{40}$ Galvin, T. J., Kent, A.: Use of a University Library Collection: A Progress Report on a Pittsburgh Study. „Library Journal” 1977, nr 102 , s. 2317-2320.

${ }^{41}$ Schad J. G.: Pittsburgh university studies of collection usage: A symposium. „Journal of Academic Librarianship" 1979, nr 5, s. 60-70.

${ }^{42}$ Bonn G. S.: Collection Analysis in Modern Librarianship. „Collection Management” 1989 , s. 73-91. W normie ISO $11620: 2004$, G. Bonn cytowany jest jako autor, który jest ekspertem w zakresie wpływu "list eksperckich" na ocene biblioteki.

${ }^{43}$ Fussler H. H., Simon L.: Patterns in the use of books in large research libraries. Chicago, The University of Chicago Press, 1969. 
Peter Brophy ${ }^{44}$, dyrektor Centre for Research in Library \& Information Management (CERLIM) w Manchester Metropolitan University twierdził, że zbieranie i ewidencja danych umożliwia poprawę zarządzania biblioteką, ponieważ dzięki relacjom, między danymi można wyraźniej dostrzec zależności między procesami realizowanymi $w$ bibliotece. P. Brophy podkreślił, że w wielu bibliotekach funkcjonuja jeszcze stare metody pracy i obsługi czytelnika. Informacja oparta jest na danych uzyskanych z elementów formalnych literatury, takich jak: autor, redaktor, wydawca i dystrybuowana jest według z góry ustalonych ścieżek procedur. Bibliotekarze moga jednak, z pożytkiem dla czytelnika, wprowadzać nowe, twórcze metody przygotowania informacji.

Day Mike i Don Revill ${ }^{45}$ stwierdzili, że Wydział Nauczania Uniwersytetu Johna Mooresa (Liverpool John Moores University) był poddany przez kierownictwo uczelni coraz silniejszej presji podnoszenia jakości pracy, tak aby produkt finalny, wytwarzany przez bibliotekę, odpowiadał jakością przeznaczonym na niego pieniądzom (pieniądze za jakość). Wydział otrzymał od kierownictwa uczelni fundusze na przeprowadzenie pomiarów. Biblioteka wykorzystała do tego celu bazę biblioteczną rejestrujaca dane na temat obrotu publikacji w bibliotece. Projekt zmierzal do stworzenia prostej analizy wykorzystania nowych nabytków. Żądane przez użytkowników pozycje były rejestrowane przez ten system. Założono, że zbadanie zarejestrowanych żądań czytelniczych pozwoli osiagnąć dwa cele:

- pozwoli na analizę wykorzystania każdej zakupionej książki w ciągu jednego roku jej „życia na półce”; da wiedzę na temat liczby wypożyczeń jednej książki; ponadto, umożliwi określenie średniej liczby wypożyczeń książek na dany temat, co jest ważne dla ustalenia kosztów poniesionych na publikacje z danej tematyki;

- pozwoli porównać wyniki wykorzystania kolekcji z wynikami podobnych badań uzyskanych przez Bibliotekę Uniwersytetu w Loughborough i z Informacją Statystyczną LISU.

Założono, że otrzymane dane, właściwie zestawione, wyłonią wartości przydatne do ewaluacji biblioteki. Te wyniki pozwolą bibliotece na zidentyfikowanie wysoko lub nisko ocenianych nowych nabytków, a przez to na określenie, jaka powinna być alokacja funduszy na zakup nowych pozycji.

Badania dotyczace wykorzystania wydawnictw omawia Allen Kent ${ }^{46}$, przedstawiając analizę badań wykorzystania czasopism w Bibliotece Uniwersytetu w Pittsburghu w 1975 r. Książka zawiera opis wykorzystania materiałów oraz

${ }^{44}$ Brophy P.: Narrative-based librarianship. [W:] The area of information and social communication: Festschrift for Professor Wanda Pindlova, „Studies in Library and Information Science" Vol. 10 Krakow, Jagiellonian University Press 2004, s. 188-195. [online]. [dostęp 10.01.2007]. Dostępny w World Wide Web: <http://www.cerlim.ac.uk/projects/ nbl_brophy.pdf. >; wersja polska Przestrzeń informacji i komunikacji społecznej. Pod red. Marii Kocójowej. Kraków 2004, seria: Zeszyty Naukowe Uniwersytetu Jagiellońskiego, nr 1274, Prace z Bibliotekoznawstwa i Informacji Naukowej, z. 10.

${ }^{45}$ Mike D., Revill D.: Towards the active collection: the use of circulation analyses in collection evaluation. „Journal of Librarianship and Information Science" 1995, nr 3, s. $149-157$.

${ }^{46}$ Kent A. i in.: Use of library materials. The University of Pittsburgh study. New York, Marcel Dekker Inc. 1979. 
ukazuje całkowity koszt związany z ich udostępnianiem, od akwizycji po wypożyczenia do domu. Badania objęły zbiór czasopism w aspekcie ilościowym, ale sprawdzono też, czy żądane przez czytelników tytuły były wykorzystane choć raz w roku. Omówiono szczegółowo procedury związane z szacowaniem wielkości wykorzystania wydawnictw ciagłych. Wyniki uzyskane na Uniwersytecie w Pittsburghu były porównywane z otrzymanymi w innych uniwersytetach amerykańskich. Ocenie końcowej podlegala nie tylko jakość wykorzystania zbiorów, ale też procedury pomiarów ${ }^{47}$.

Roswitha Poll, przy współudziale Philipa Payne'a ${ }^{48}$, napisała pracę, w której pokazała, że wiele projektów badawczych obejmuje nie tylko badania statystyczne, ale też przedstawia związki funkcjonowania biblioteki z umiejętnościami i kompetencjami jej użytkowników. Użytkownicy są beneficjantami pracy biblioteki, a tę pogłębiającą się wiedzę i doświadczenie klientów można mierzyć. Są to rosnące kompetencje $w$ samodzielnym wykorzystaniu informacji, a także sukces naukowy i zawodowy, integracja społeczna i wreszcie dobrobyt. Artykuł prezentuje metody przydatne do pomiarów naukowych: umożliwiaja one prezentację działalności biblioteki w różnych aspektach, także w benchmarkingu między instytucjami. Autorka prezentuje korzyści wynikające z wykorzystania tak zwanych „miękkich metod”. Zalicza do nich obserwację, wywiad, test, analizę publikacji oraz metody ilościowe wykorzystujące dane wynikające z funkcjonowania biblioteki. Tekst zaopatrzono w bogatą bibliografię.

\section{Katalogi}

W pierwszym czterdziestoleciu po drugiej wojnie światowej znaczna część prac bibliotekarskich w Stanach Zjednoczonych koncentrowała się na polepszeniu jakości wytwarzanych przez bibliotekę systemów informacyjnych ${ }^{49}$. Badania dotyczyły sposobów wykorzystania katalogów przez poprawę skuteczności wyszukiwań, głównie w katalogach rzeczowych, oraz - doskonalenia procesów organizacyjnych w bibliotekach, tak aby wykorzystanie zbiorów było jak najpełniejsze. Zasadnicze postulaty na temat modernizacji tworzenia katalogów znalazły się w cytowanej pracy F. Ridera z $1944 \mathrm{r}^{50}$.

Do tezy głoszonej przez Ridera, że zbiory bibliotek podwajają się co 16 lat a wraz z nimi również liczba załogi bibliotecznej ${ }^{51}$, krytycznie odniósł się Colin

\footnotetext{
${ }^{47}$ Między innymi w zestawieniu bibliograficznym do pracy M. S. Sridhar: A case study of lentout use of a special library. Library Science With a Slant to Documentation 1985, nr 22 s. 19-34; M.S. Sridhar: Studies on use of library collections by scientists, engineers and technicians. „Aglis Journal" 1987, nr 4, s. 9-17. [online]. [dostęp: 16.03.2008]. Dostępny w World Wide Web: <http:/l eprints.rclis.org/archive/00012340/>; Broadus R. N.: The Application of Citation Analyses to Library Collection Building. „Advances in Librarianship" 1977, t. 7, s. 299-335.

${ }^{48}$ Poll R., Payne P.: Impact measures for libraries and information services. „Library Hi Tech" 2006, nr 24/4, s. 547-562. [online]. [dostęp: 04.2007]. Dostępny w World Wide Web: <http://conference.ub.uni-bielefeld.de/2006/proceedings/payne_poll_final_web.pdf >

${ }^{49}$ Problematyki tej dotyczył również referat wygłoszony na III Bałtyckiej Konferencji „Zarzadzanie i Organizacja Bibliotek” pod hasłem „Standardy bibliotek europejskich”. Gdańsk, 2829 maja 2009: T. U. Szmigielska: Geneza tworzenia standardów oceny pracy biblioteki akademickiej.

${ }^{50}$ Rider F.: The scholar..., op. cit.

51 Ibidem, s. 8.
} 
Steele ${ }^{52}$, dowodząc, że jeśli przyjąć rozwój zbiorów według Ridera, to Biblioteka Uniwersytetu w Yale liczyłaby pod koniec lat siedemdziesiątych ok. $50 \mathrm{mln}$ wol., a dział katalogowania zatrudniałby ok. 5 tys. bibliotekarzy. Podobne tezy jak C. Steele głosił R. E. Molyneux ${ }^{53}$.

Badania katalogów w drugiej połowie dwudziestego wieku dotyczyły jednej lub kilku wybranych bibliotek i polegały na badaniu jakości katalogu na podstawie stosunku liczby poprawnych wyszukiwań do ogólnej liczby poszukiwań w katalogu rzeczowym ${ }^{54}$. James Krikelas ${ }^{55}$ udowodnił, że forma pytań zadawanych przez użytkownika ma wpływ na stopień powodzeń w kwerendach bibliotecznych. Problemy z udostępnianiem katalogów w formie papierowej zostały częściowo rozwiązane przez ich umieszczenie w Internecie. Badania przeprowadzone w omawianym czterdziestoleciu posłużyły do tworzenia wskaźników funkcjonalności umożliwiających ocenę jakości katalogów uporządkowanych formalnie i rzeczowo.

\section{Zestaw narzędzi do badania jakości pracy biblioteki}

Karen E. Fisher, autorka i współautorka kilku książek i kilkudziesięciu artykułów w najważniejszych naukowych periodykach bibliotekoznawczych, jest często cytowana w bibliografiach załącznikowych ${ }^{56}$. Jej publikacja The Outcomes Toolkit 2.0 prezentuje zestaw narzędzi pozwalających tak zorganizować funkcjonowanie biblioteki i jej usług, aby była ona wartościowym warsztatem pracy naukowej dla pracowników dydaktycznych oraz studentów uniwersytetu. Przedstawiono czynności niezbędne do ewaluacji biblioteki: planowanie, zbieranie i analizę danych oraz ich wykorzystanie.

Jak pomóc użytkownikom biblioteki w rozwiązywaniu ich problemów, radzą Rosemary N. Chacha i Ann Irving na przykładzie badań ankietowych, przeprowadzonych w 1990 r. na uniwersytecie w Loughborough w Wielkiej Brytanii, wśród losowo wybranych studentów ${ }^{57}$. Badania te miały dostarczyć informacji,

${ }^{52}$ Steele C.: op. cit.; oprócz cytowanej tu pracy z obszerną bibliografią omawiającą literaturę na temat tez głoszonych przez F. Ridera, C. Steele jest twórca wielu publikacji krytycznych wobec jego twórczości, m.in.: Steady-State, Zero Growth and the Academic Library. London, Bingley 1978.

${ }^{53}$ Molyneux R. E.: Patterns, processes of growth, and the projection of library size: a critical review of the literature on academic library growth. „Library \& Information Science Research" 1986, nr 8, s. 5-28.

${ }^{54}$ Frarey, C. J.: Studies of Use of the Subject Catalog: Summary and Evaluation. [w:] Subject Analysis of Library Materials. Pod red. M. F. Tauber, New York, Columbia University, School of Library Service 1953, s. 147-166; także Tagliacozzo R., Kochen, M.: InformationSeeking Behavior of Catalog Users. "Information Storage and Retrieval” 1970, nr 6, s. 363-381.

${ }^{55}$ Krikelas, J.: Searching the library catalog-A study of users' access. „Library Research" 1980, nr 2, s. 215-230; J. Krikelas obecnie również prowadzi podobne badania w odniesieniu do katalogów online.

${ }^{56}$ Durrance J. C., Karen E. Fisher: The Outcomes Toolkit 2.0. Ann Arbor, MI and Seattle, University of Michigan and University of Washington 2002. [online]. [dostęp: 1.04.2007]. Dostępny w World Wide Web: <http://ibec.ischool.washington.edu/ibecCat.aspx?subCat $=$ Outcome $\% 20$ Toolkit\&cat $=$ Tools $\% 20$ and $\% 20$ Resources $>$

${ }^{57}$ Chacha R. N., Irving A.: An experiment in academic library performance measurement. „British Journal of Academic Librarianship” 1991, nr 1, s. 16-26. 
z jakimi trudnościami spotykają się użytkownicy bibliotek, a następnie poddać wyniki analizie i zaproponować rozwiązania. Najważniejszymi problemami czytelników okazały się:

- odnalezienie autora w katalogu, kiedy były znane nie całe imiona, a jedynie ich inicjały,

- odnalezienie tytułu czasopisma w odrębnym katalogu,

- otrzymanie publikacji w krótkim czasie, gdy w zbiorach przeważaja pojedyncze egzemplarze.

Wyniki badania przedstawiono bibliotekarzom i nauczycielom akademickim. Po wspólnych naradach uznano dotychczasowe metody przyswajania wiedzy bibliotecznej na tak zwanym „szkoleniu bibliotecznym” za niedostateczne. Stwierdzono, że również nauczyciele muszą zwracać baczną uwagę na metody stosowane przez studentów poszukujących źródeł. Zdecydowano, że jedynie bliska współpraca naukowców, bibliotekarzy i studentów zapewni właściwe przygotowanie tych ostatnich do efektywnego korzystania ze źródeł. Finansowanie biblioteki, zdaniem naukowców, powinno być uzależnione od satysfakcji jej użytkowników.

Pracę omawiającą zastosowanie narzędzi do wartościowania pracy biblioteki opublikowali amerykańscy badacze John C. Durrance i K. E. Fisher ${ }^{58}$. Zwracaja oni uwagę na zjawisko zdeterminowania procedur i rodzaju zbieranych danych oraz zastosowanych narzędzi przez rodzaj pomiaru, jaki biblioteka zamierza wykonać. Badają również, czy w bibliotece są warunki do pracy indywidualnej i grupowej, ułatwiające studentom naukę. W kontekście czynników zdeterminowanych przez jakość pracy biblioteki rozważa się jakość studiowania na uczelni.

Podobnie ujmuje temat praca Johna C. Durrance'a, Karen E. Fisher i Marian Bouch Hinton ${ }^{59}$. Zawiera ona wyjaśnienie podstawowych pojęć oraz omówienie przygotowania modelu logicznego wyników pracy biblioteki, planu zbierania danych, a także ich wykorzystania.

W bibliografiach zalącznikowych często cytowane są publikacje Amerykanina Petera Hernona ${ }^{60}$. P. Hernon jest profesorem w Graduate School of Library and Information Science at Simmons College w Bostonie. Opublikował 37 książek, był redaktorem Journal of Academic Librarianship, współredaktorem Library \& Information Science Research oraz Government Information Quarterly. Zajmuje się problematyka jakości pracy biblioteki w kontekście zadowolenia klienta oraz popularyzacją praktycznych metod pomiaru jakości pracy biblioteki. Pierwsza praca, napisana wspólnie z Ellen Altman ${ }^{61}$, różni się od innych publikacji poświęconych tematowi ewaluacji jakości: autorzy odrzucają w niej oce-

${ }^{58}$ Durrance J. C., Fisher K. E.: Determining how libraries and librarians help. „Library Trends" 2003, nr 51, s. 305-334. [online]. [dostęp: 15.04.2007]. Dostępny w World Wide Web: <http://www.ischool. washington edu/fisher/pubs/library.trends.2003.pdf.>

${ }^{59}$ Durrance J. C., Fisher K. E., Hinton M. B.: How Libraries and Librarians Help. A Guide to Identifying User-Centered Outcomes. Chicago, American Library Association 2005.

${ }^{60}$ Norma ISO 11620 Poll R., Boekhorst P. Measuring Quality. Op. cit., s. 10.

${ }^{61}$ Hernon P., Altman E.: Service quality in Academic Libraries. Greenwood Publishing Group, 1996. [online]. [dostęp: 14.05.2008]. Dostępny w World Wide Web: <http://books.google.pl/books? id=3BXSV2NptKQC\&pg=PA15\&source=gbs_toc_r\&cad=0_0\&sig=Z_uK suLPXFOI_UZKo jFnts1tQ_1> 
nę pracy biblioteki z punktu widzenia pracownika, przyjmując punkt widzenia odbiorcy usług - klienta, prezentuja sposoby pomiaru jakości wyników pracy instytucji, identyfikuja podstawowe elementy jakości i kosztochłonności. Hernon i Altman wykorzystali dwuletnie badania do sformułowania praktycznych porad dla kadry zarządzającej. Ich praca dostępna jest w Internecie.

Druga publikacja to artykuł Hernona opublikowany w $2002 r^{62}$, w którym autor zadaje kluczowe według niego pytania dla właściwego rozumienia problemu jakości w bibliotece, w której zatrudniony jest pracownik dokonujący jej pomiarów:

- Jaka jest w bibliotece jakość obsługi i satysfakcja klienta? Czy można wyszukać i określić różnice $w$ ocenie jakości pracy biblioteki przez klienta i bibliotekarza?

- Jak można mierzyć satysfakcję klientów wynikającą z obsługi bibliotecznej?

- Czy jest możliwe właściwe oszacowanie wpływu biblioteki na odbiorców?

- Jak może być oszacowana jakość pomiaru?

- Czy i jakie są relacje między wynikami pomiaru a jakością obsługi i satysfakcją klientów z pracy biblioteki?

Trzecia praca powstała we współpracy z Robertem E. Duganem ${ }^{63}$. Jest to praktyczny podręcznik dotyczący pomiaru wyników pracy biblioteki. Zawiera on także studia przypadków oraz wyniki dyskusji bibliotekarzy na temat, jak przygotować pomiar wyników pracy biblioteki, plan zbierania i analizy danych oraz jak mierzyć jakość obsługi bibliotecznej. Ważny jest także wspólny artykuł Petera Hernona i Roberta E. Dugana ${ }^{64}$ będący zapisem wcześniej wygłoszonego referatu na internetowej konferencji IFLA.

\section{Ewaiuacja w drugiej połowie dwudziestego wieku}

W latach 60. i 70. rozpoczęto ewaluację bibliotek w państwach europejskich. W maju 2006 r. opublikowano w Internecie sprawozdanie Komitetu Edukacji dla Zdrowia ${ }^{65}$. Znajduje się w nim opracowanie omawiające działalność francuskiej grupy roboczej powołanej do spraw ewaluacji bibliotek. Na końcu pracy umieszczono bibliografię, zawierającą najważniejsze prace, a wśród nich książki i artykuły. Jako pierwszą pracę, dotyczącą ewaluacji, zarejestrowano publikację F. M.

${ }^{62}$ Hernon P.: Quality: New directions in the research. „Journal of Academic Librarianship" 2002, nr 28, s. 224-231.

${ }^{63}$ Hernon P., Dugan R. E.: An action plan for outcomes assessment in your library. Chicago, American Library Association, 2002.

${ }^{64}$ Hernon P., Dugan R. E.: Different perspectives on assessment and evaluation: The need to refine and link them. „Proceedings of the 5th Northumbria International Conference on Performance Measurement in Libraries and Information Services 2003", Northumbria University 2004, s. 23-30. [online]. Dostępny w World Wide Web: <http://www.emeraldinsight. com InsightviewContentltem.do;jsessionid=782B6DC4437CCB0DBFCC1DD92F8 C270B? contentType=Article\&hdAction=Inkhtml\&contentld=1581949\&dType=SUB\&history $>$

${ }^{65}$ Éléments méthodologiques d'évaluation de l'activité de documentation dans les comités d'éducation pour la santé 2002. [online]. [dostęp: 16.05. 2008]. Dostępny w World Wide Web: <http://craes-crips.com/pub/fixes/21_elements_devaluation_activite_doc_ 2006.pdf> 
Katza z 1978 r. ${ }^{66}$. Następne wydawnictwo cytowane w sprawozdaniu Komitetu A. Deccache z $1989 r^{67}$ jest o ponad dziesięć lat późniejsze.

Historyczne ujęcie dokumentujace rozwój badań nad ewaluacja można znaleźć w artykule Pierre'a Carbone'a ${ }^{68}$. Prezentuje on początek przemian dotyczacych pomiaru jakości pracy, dokonujących się w bibliotekach publicznych i akademickich w ostatnich dwudziestu latach XX w. W artykule sprzed ponad 15 lat autor przedstawił korzyści z pomiaru wykonania zadań oraz koszty z tym zwiazane. Opis dotyczy wskaźników funkcjonalności służb informacyjnych i przedstawia doświadczenia grupy roboczej badającej jakość pracy bibliotecznej. Autor dochodzi do wniosku, że rozmaite dane, zbierane w bibliotekach różnych rodzajów, wymagają stworzenia jasnej definicji pomagającej w określeniu, jakie jest znaczenie konkretnej biblioteki, jej misja i miejsce w lokalnym i narodowym otoczeniu. W procesie przemian bibliotecznych to biblioteki akademickie były tymi, które rozpoczęły i znajdowały się w czołówce badań nad pomiarami wykonania zadań.

Problematyką oceny bibliotecznych służb informacyjnych zajął się też JeanPhilippe Lamy ${ }^{69}$. Do oceny metod zarządzania i efektywności pracy bibliotek od kilku lat we Francji stosowana jest norma NF ISO 11620 Wskaźniki działalności bibliotek, nie umożliwia ona jednak oceny bibliotecznych służb informacyjnych. J. P. Lamy przedstawia inny, oparty na literaturze brytyjskiej, schemat postępowania. Pierwsza część raportu oceniającego pracę służb informacyjnych wymienia dane ilościowe, w drugiej części raportu J. P. Lamy omawia wskaźniki skuteczności dotyczące wykorzystania tych danych: zbiorów, obsługi informacyjnej. Dla przykładu, wskaźnik działalności informacyjnej na osobę uzyskuje się, sumując liczbę odpowiedzi, a wynik - dzieląc przez liczbę potencjalnych użytkowników. Te wyniki należy porównać z liczbą wypożyczeń podzielonych przez liczbę potencjalnych użytkowników. Wyniki wskaża, jaka jest aktywność służb informacyjnych oraz jaka jest intensywność wykorzystania zbiorów.

W innym artykule ${ }^{70}$ podany jest przykład badań zainspirowanych przez francuskie wydanie normy ISO 11620. Zgodnie z postulatami pracowników informacji, francuska agencja normalizacyjna ANFOR ogłosiła w 1998 r. normę NF ISO 11620 Wskaźniki efektywności pracy bibliotek. Bibliotekarze postanowili uzupełnić wskaźniki proponowane przez normę o inne, niezbędne do oceny pracy służb informacyjnych, i zbadać poziom satysfakcji użytkowników ze świadczonych usług. Wyznaczono wskaźniki jakościowe: jakość źródła informacji (oceniana przez eksperta dokumentalistę na podstawie aktualności i dokładności informacji), wartość dodana przez pracownika informacji - polegająca na zrozumieniu, doprecyzowaniu pytania zadanego przez czytelnika, właściwym dobo-

\footnotetext{
${ }^{66}$ Katz F. M.: Directives pour évaluer un programme de formation des personnels de santé. Geneve, OMS 1978.

${ }^{67}$ Deccache A.: Pour mieux choisir son evaluation. Liege, APES, 1989.

${ }^{68}$ Carbone P.: Survey of the Development of Library Performance Measures in France. „INSPEL" 1993, nr 3, s. 196-198.

${ }^{69}$ Lamy J. P.: Évaluer un service de référence, quelques outils. „Bull. Bibl. France” 2001, t. $46, \mathrm{nr} 4, \mathrm{~s} .82-88$.

${ }^{70}$ Briand B., Buffeteau A., Cudelou J.-F. i in.: Indicateur de performance des services documentaire , l'expérience d'un groupe de professionnels de l'information. „Documentaliste" 2002, nr 1-2, s. 26-33.
} 
rze źródeł, satysfakcja użytkowników - zależna od czasu oczekiwania na odpowiedź, a także od otrzymania wyczerpujacej informacji.

Problematyką ewaluacji biblioteki w kontekście zarządzania od lat siedemdziesiątych zajmował się Wilfrid F. Lancaster. Napisał on kilkadziesiąt książek dotyczących pomiaru efektywności pracy biblioteki, cytowanych we wszystkich bibliografiach na ten temat Poznał dobrze problematykę bibliotekarstwa światowego, ponieważ z ramienia UNESCO pracował między innymi w Argentynie, Brazylii, Meksyku, Norwegii, a także w Polsce

Książka F. W. Lancastera ${ }^{71}$ uważana jest za jedną z zasadniczych prac mówiących o metodach pomiaru wykorzystania zbiorów. Autor daje w niej definicję ewaluacji: ocena z użyciem określonych metod. Jego zdaniem, ewaluacja pomaga w podejmowaniu decyzji, dając jednocześnie wiedzę o możliwych innych rozwiązaniach, pomaga przy zarządzaniu alokacją zbiorów. Lancaster kładzie nacisk na prawidłowe informowanie użytkowników o zbiorach. W publikacji zawarty jest przegląd narzędzi przydatnych w pomiarach jakości pracy biblioteki. Jedną $z$ najciekawszych metod, szeroko stosowanych $w$ zarządzaniu ${ }^{72}$, jest reguła 80/20 mówiąca, że w wielu konkretnych sytuacjach 80 procent konsekwencji wypływa z 20 procent przyczyn. Konkretne sytuacje są sprawdzone empirycznie i można dowieść, że:

- ok. 80 procent błędów wynika z 20 procent przyczyn,

- ok. 80 procent sprzedaży realizowanych jest przez 20 procent sprzedawców,

- w ok. 20 procentach (grup) pozycji magazynowych zamrożonych jest 80 procent wartości zapasów.

Późniejsza książka Lancastera ${ }^{73}$ omawia techniki pomiarów wykorzystujące obiektywne procedury. Autor podkreśla, że ewaluacja biblioteki to stały wysiłek przynoszący odpowiedź na pytanie, w jakim zakresie biblioteka spełnia swoje zadania. Jest on zdania, że ewaluacja powinna określać, jak biblioteki zachowują się w zmieniającej się rzeczywistości, powinna też być narzędziem rozpoznawania słabych stron, błędów i niedociąnięć, co pozwoliłoby polepszyć pracę biblioteki.

Lancaster zadaje pytanie, czym jest ewaluacja, i odpowiada, że jest ona:

- szacowaniem wartości z użyciem metod naukowych,

- podejmowaniem decyzji z uwzględnianiem alternatyw,

- alokacją zasobów za pomocą narzędzi zarządzania.

Według Lancastera ewaluacja zawiera elementy praktyki i jest pomocna w rozwiązywaniu problemów praktycznych. Książka ta jest cytowana w zaleceniach IFLA ${ }^{74}$ jako praca zawierająca dobry opis wskaźników przydatnych do obliczania wykorzystania zbiorów w aspekcie rzeczowym.

${ }^{71}$ Lancaster F. W.: If you want to evaluate your library. Wyd. 2, Champaign, University of Illinois, 1993, s. 76-85 [wyd. pierwsze 1988]; na tę pracę powołują się też autorzy w polskich tematycznych zestawieniach bibliograficznych.

${ }_{72}$ Patrz strona domowa portalu Dyrekcja Techniki jakości, prawo 80/20. [online]. [dostęp: 10.12.2008]. Dostępny w World Wide Web: <http://dyrekcja.objectis.net/ biblioteka/ techniki/quality/analizaabc>

${ }^{73}$ Baker S. L., Lancaster F. W.: The measurement and evaluation of library services. Wyd. 2, Information, Resources Press, Arlington 1991, s. 79-121. [ wyd. pierwsze 1977].

${ }^{74}$ Poll R., Boekhorst P.: Measuring Quality;..., op. cit. 
F. W. Lancaster i Shiao-Feng Su ${ }^{75}$ podjęli próbę oceny komputerowych systemów typu ekspertowego przeznaczonych do poszukiwania źródeł informacyjnych. Jest to ocena efektywności wyszukiwania źródeł informacji przy wykorzystaniu dwóch systemów komputerowych typu ekspertowego oraz porównanie wyników z rezultatami osiagniętymi przy pomocy doświadczonych bibliotekarzy. Okazało się, że systemy zautomatyzowanej informacji są zdecydowanie mniej doskonałe od porad bibliotekarza. Badanie wykazało, jak ważne jest testowanie przydatności systemów wspomagających wyszukiwanie przed ich zakupem. Jest ono także wskazówką do dalszego doskonalenia tych systemów. Książki Lancastera, które od lat siedemdziesiątych definiują pojęcia i wyznaczają kierunki badań, są ciągle wznawiane.

Analizę przejścia od pomiarów wyłącznie matematycznych do pomiarów subiektywnej oceny biblioteki przez czytelnika podejmuje Deborah L. Goodall ${ }^{76}$. W artykule omawia historię rozwoju wskaźników funkcjonalności od końca lat sześćdziesiątych do połowy osiemdziesiątych. Praca jest szczególnie ważna, bo początkowe lata rozwoju pomiarów wykonania zadań w środowisku europejskich akademickich bibliotek naukowych są mniej znane od amerykańskich. Autorka analizuje historię pomiarów, łącząc ją z powstającymi równolegle pracami naukowymi omawiającymi wyniki badań ${ }^{77}$.

Zalecenia międzynarodowej unifikacji statystyki bibliotecznej UNESCO i prace statystyczne w NRD omówił E. Klempin ${ }^{78}$. Zreferował wysitki IFLA i UNESCO, czynione od 1968 r., nad ujednoliceniem statystyki bibliotecznej w skali światowej. Zalecenia zawierają wykaz szczegółowych wskaźników pozwalających na zróżnicowanie typów bibliotek, od głównych - narodowych do małych - publicznych. Dane ze 137 krajów za rok 1984 zamieszczone zostały w Roczniku Statystycznym UNESCO. Bibliotekarze niemieccy opracowali statystykę biblioteczną w NRD od 1949 r. Całością prac, zmierzających do maksymalnej porównywalności danych w obiegu międzynarodowym, kierowało Centrum Metodyczne Bibliotek Naukowych Ministerstwa Szkolnictwa Wyższego i Zawodowego ówczesnego NRD.

Wieloletni dyrektor Biblioteki Politechniki Newcastle, Jan Winkworth ${ }^{79}$, w artykule zamieszczonym w periodyku Library Review, przedstawił swoje do-

${ }^{75}$ Shiao-Feng S., Lancaster F. W.: Evaluation of expert systems in reference service applications. „RQ" 1995 , vol. 35 , nr 2 , s. 219-228.

${ }^{76}$ Goodall D. L.: Performance measurement: A historical perspective. „Journal of Librarianship" 1988, nr 2, s. 128-144

${ }^{77}$ Przykładowo: Powell, R. R.: The relationship of library user studies to performance measures: A review of the literature. (Occasional Papers, no. 181), University of Illinois Graduate School 1988, nr 181; Douglas R.: Performance measurement and performance indicators. A selective bibliography. [online]. [dostęp: 10. 01. 2008]. Dostępny w World Wide Web: <http://searchrecherche.collectionscanada.ca/fed/searchResults.jsp?SourceQuery $=\&$ Result Count $=5 \&$ PageNum $=1 \&$ MaxDocs $=-\&$ SortSpec $=$ score + desc $\&$ Language $=$ eng\&Sources=amicus\&Sources=mikan\&Sources=web\&Query Text=Bibliography + series $+\% 238>$

${ }^{78} \mathrm{Klempin}$ E.: Recommendation concerning the international standardization of library statistics der Unesco und die bibliotheksstatistischen Arbeit in der DDR. „Zentralbl. Bibl.Wes" 1988 , s. 49-55, s. 108-114.

${ }^{79}$ Winkworth J.: Performance indicators for polytechnic libraries. „Library Revew” 1990, nr 5, s. 23-41. 
świadczenia w ustalaniu ilościowych i jakościowych wskaźników badania pracy biblioteki. Metody oceny wydajności pracy w bibliotekach politechnicznych sa odmienne na przykład od bibliotek humanistycznych. Wynika to z odmienności zbiorów oraz innych struktur porządkowania działów zawierających opisy działalności praktycznej. Autor prezentuje wskaźniki efektywności na przykładzie doświadczeń zdobytych w Bibliotece Politechniki Newcastle. Proponuje uwzględnienie w ocenie pracy biblioteki takich wskaźników jak: dostępność dokumentów w zbiorach, koszty udostępnienia publikacji, koszt udzielanych informacji. Dzięki gromadzeniu takich podstawowych danych można będzie dokonać porównań z innymi podobnymi bibliotekami.

Problematyką ewaluacji bibliotek działających w sieci zajmował się, wspomniany już wcześniej, Thomas Childers ${ }^{80}$. W pracach na ten temat zadaje on pytanie, w jakim stopniu przynależność bibliotek do sieci ma wpływ na poziom ich pracy. Badania przeprowadzono za pomocą kwestionariusza i wywiadów. Wnioski z tych badań, zachęcające do współpracy w sieci bibliotecznej, są następujące:

- biblioteki są w systemie niezależne, pozostawiając organizacji nadrzędnej niektóre funkcje;

- obserwuje się, że mimo mniejszych środków finansowych biblioteki zrzeszone rozwijają się szybciej, a wykorzystanie w nich księgozbioru jest intensywniejsze;

- szczególnie szybko rośnie liczba wypożyczeń międzybibliotecznych.

Badacz niemiecki G. Reichmann ${ }^{81}$ rozważał wpływ wielkości biblioteki na wskaźniki statystyczne. W opisywanym badaniu jako próbę przyjęto trzydzieści niemieckich bibliotek wyższych szkół zawodowych. Podzielono je na duże i małe. Pierwsze to takie, w których pracuje co najmniej 10 pracowników w pełnym wymiarze godzin. Podstawę porównań stanowiły następujące wskaźniki ilościowe: liczba pracowników, wielkość księgozbioru w jednostkach inwentarzowych, liczba stanowisk komputerowych w porównaniu do liczby użytkowników, godziny otwarcia czytelni, przyrost księgozbioru w roku kalendarzowym, liczba wypożyczeń z wylączeniem międzybibliotecznych, liczba studentów. Zastosowano również wskaźniki złożone, takie jak: wielkość księgozbioru na jednego studenta, przyrost księgozbioru na studenta, wielkość powierzchni na studenta, liczba studentów na jedno stanowisko komputerowe, liczba wypożyczeń w porównaniu do liczby pracowników biblioteki, stosunek liczby studentów do liczby pracowników, liczba wypożyczeń na jednego studenta, stosunek liczby wypożyczeń do wielkości księgozbioru.

Badania wykazały, że jeśli weźmie się pod uwagę dane statystyczne, to większe biblioteki maja lepsze wyniki. Jeżeli chodzi natomiast o wskaźniki funkcjonalności, takie jak: liczba studentów przypadająca na jedno stanowisko komputerowe czy liczba wypożyczeń w przeliczeniu na wielkość księgozbioru - tzw. wskaźnik aktywności księgozbioru - to biblioteki małe są lepsze od dużych.

${ }^{80}$ Childers T.: Measures of interlibrary reference. A manual. Sacramento, California State Library Foundation 1991.

${ }^{81}$ Reichmann G.: Size matters, Einfluss der Bibliotheksgrösse auf Bibliothekskennzahlen am Beispiel von Fachhochschulbibliotheken. „Buch und Bibliothek” 2003, nr 55, s. 235-239. 
Othmar F. Fett ${ }^{82}$ przedstawia na stronie internetowej Uniwersytetu Humboldta publikację, w której poddaje pod dyskusję zastosowanie metod angloamerykańskich dla badania korzyści wynikających z funkcjonowania biblioteki akademickiej. Omawia doświadczenia opisane w literaturze anglojęzycznej, porównując je do sytuacji w Niemczech. Próbuje odpowiedzieć na pytanie, jaka jest rola i miejsce biblioteki w jakości kształcenia akademickiego. W obszernym tekście występują powołania na LibQUAL+, ISO 11620 Informacja i dokumentacja..., ISO TR 20983 Informacja i dokumentacja. Statystyka biblioteczna oraz wskazówki IFLA. Jest to bogaty materiał historyczny i krytyczny, do którego dołączono spis publikacji analizujących programy ewaluacji bibliotek. Szczególną uwagę przywiązuje autor do publikacji Roswithy Poll dotyczących pomiarów jakości pracy w bibliotekach naukowych ${ }^{83}$.

Trwające od ponad stu lat pomiary jakości pracy bibliotek amerykańskich i od ponad trzydziestu lat europejskich znalazły zagorzałych zwolenników i równie bezwzględnych krytyków. Do tych drugich należy australijska badaczka Jennifer $\mathrm{Cram}^{84}$, która krytycznie zarysowuje problemy związane z ewaluacją biblioteki. Zwraca uwagę na potrzebę wielokierunkowych badań posługujacych się narzędziami behawiorystycznymi, psychologicznymi, ekonomicznymi. Uważa, że jest wiele dwuznaczności i sprzeczności w interpretacji ocen pracy biblioteki. Wysuwa tezę, że precyzyjne mierzenie wartości pracy biblioteki jest niemożliwe, gdyż wyniki pomiarów będą uzależnione od nie zawsze spójnych interesów bibliotekarzy, klientów i zarządu.

Z kolei praca Briana Quinna ${ }^{85}$, socjologa i bibliotekarza oraz nauczyciela akademickiego w Texas Tech University, porównuje poczynania bibliotek (mające na celu poprawę jakości produktu przekazywanego przez bibliotekę w postaci informacji) do zabiegów firmy Mac Donalds. Autor, choć ma wątpliwości co do bezkrytycznego przenoszenia rozwiązań z instytucji sprzedającej tzw. fast food na bibliotekę, to jednak uważa, że instytucje naukowe mają szansę na kreatywne podejście do współpracy z odbiorcą.

${ }^{82}$ Fett O. F.: Impact - Outcome - Benefit. Ein Literaturbericht zur Wirkungsmessung für Hochschulbibliotheken. Berlin, 2004. [online]. Dostępny w World Wide Web: <http://www. ib.hu-berlin.de/ kumlau/handreichungen/h142/>

${ }^{83}$ Poll R.: Kann man die "Wirkung” von Bibliotheken messen? Internationale Projekte zu „impact" und „outcome "in öffentlichen und wissenschaftlichen Bibliotheken. 92 Deutscher Bibliothekartag in Augsburg 200. Frankfurt a. M., Klostermann „Zeitschrift für Bibliothekswesen und Bibliographie" 2003, s. 357-369; Impact/outcome measures for libraries. "Liber Quarterly" 2003, nr 3/4, s. 329-342. [online]. Dostępny w World Wide Web: <http://liber.library.uu.nl/>; Was dabei herauskommt. Wirkungsforschung für Bibliotheken. "Zeitschrift für Bibliothekswesen und Bibliographie" 2005, nr 2-3, s. 59-70.

${ }^{84}$ Cram J.: Six impossible things before breakfast. A multidimensional approach to measuring the value of libraries. [w:] Proceedings of the 3rd Northumbria International Conference on Performance Measurement, „Libraries and Information Services" 1999, Newcastle upon Tyne 2000, s. 19-29. [online]. [dostęp: 17.04.2007]. Dostępny w World Wide Web: <http://www.alia.org.au/ jcram/six_things.html>

${ }^{85}$ Quinn B.: The McDonaldization of Academic Libraries? [online]. [dostęp: 14.05. 2008]. Dostępny w World Wide Web: <http://web2.ala. org/ala/acrl/acrlpubs/crljournal/ backissues2000b/may00/quinn.pdf> 
Niemiecki bibliotekarz Simon Xalter ${ }^{86}$ opublikował analizę rankingu bibliotek naukowych na stronie internetowej BIX - Bibliotheksindex. Uważa on, że tego typu badania można przeprowadzać na przykład w polityce, natomiast w przypadku instytucji kultury miejsce w rankingu może zawsze być uzależnione od z góry przyjętych kryteriów, faworyzujących jedne, a krzywdzących inne biblioteki. Strona internetowa BIX zawiera wiele artykulów krytykujących ideę rankingów dla bibliotek naukowych. Stanowi ona bogaty zasób, uzupełnianych na bieżąco, ròżnorodnych materiałów dotyczących pomiaru bibliolek.

\section{Zastosowanie norm do pomiaru jakości pracy biblioteki}

Problematykę tę podjęli S. D. Lithgow oraz A. Mac Dougall ${ }^{87}$ na 57 Kongresie IFLA w Moskwie. Stwierdzili, że w ostatnich dekadach XX w. nie dokonano w skali światowej unifikacji norm oceny efektów pracy bibliotek. Główne przyczyny to brak jednoznacznego zdefiniowania terminów oraz różnice kulturowe między poszczególnymi krajami. Zbieranie danych statystycznych i porównywanie bibliotek są zjawiskami rzadko spotykanymi, ponieważ bibliotekarze obawiaja się, że w rezultacie badań nastąpi ograniczanie funduszy na działalność ich placówek, a jednocześnie zwiększanie wymagań stawianych im przez instytucje nadrzędne ${ }^{88}$. Autorzy postulowali konieczność wszechstronnych badań, które umożliwiłyby opracowanie stosownych norm i podręczników. Niezbędne jest ich zdaniem dokonanie przez IFLA analizy norm i wskaźników oceny efektywności pracy bibliotek stosowanych w różnych krajach oraz stworzenie norm międzynarodowych.

W artykule Thomasa J. Hennena ${ }^{89}$ omawiana jest problematyka stosowania norm. Po niespełna dwudziestu latach od cytowanego poprzednio wystapienia w Stanach Zjednoczonych kłopotliwe stało się równoległe stosowanie różnych norm. Z tego powodu autor postulował ustalenie krajowego systemu norm. Normy określające wymagania wobec poziomu usług bibliotecznych ustalają różne instytucje, na przykład akredytacyjne, finansujące działalność na szczeblu stanowym i wewnątrz samej biblioteki. Jeśliby ustanowiono normy krajowe, to stałyby się one impulsem do podnoszenia poziomu usług. Normy określiłyby wymagany poziom przygotowania zawodowego pracowników, jakości wyposażenia, proponowanej powierzchni i budżetu bibliotecznego. Priorytetem powinno się stać - zdaniem Hennena - wprowadzenie do oceny jakości norm ISO 9000 .

Badacz francuski J. H. Spohrer ${ }^{90}$ napisał artykuł na temat możliwości badań porównawczych pracy bibliotek francuskich i amerykańskich. Według autora

\footnotetext{
${ }^{86}$ Xalter S.: Der „Bibliotheksindex" (BIX) für wissenschaftliche Bibliotheken - eine kritische Auseinandersetzung. [online]. [dostęp: 20.08.2007]. Dostępny w World Wide Web : <http://w210.ub.unituebingen.de/dbt/volltexte/2006/2440/pdf/BIX_OPUS_Tue_Xalter.pdf>

${ }^{87}$ Lithgow S. D., MacDougall A.: Performance assessment, töday's confusion, tomorrow's solution? "IFLA Journal” 1991, nr 4, s. 371-378.

${ }^{88}$ Ten temat omówiono szerzej w punkcie 1. Koszty.

${ }^{89}$ Hennen T. J.: Why we should establish a national system of standards. „Amer. Library" 2000 , t. 31 , nr 3, s. 43-45.

${ }^{90}$ Spohrer J. H.: Les bibliothéques universitaires françaises et nord-américaines prolégomenes a une étude comparative. „Bull. Bibl. France” 2002, nr 5, s. 32-35.
} 
w Stanach Zjednoczonych dane były zbierane od osiemdziesięciu lat (ostatnio publikowano na stronie internetowej Association of Research Libraries Statistics). We Francji utworzono przy ESGBU (L'Enquęte Statistique Générale Auprés des Bibliothčques Universitaires) komórkę zbierającą dane od bibliotek uczelnianych. Kwestionariusz obejmuje 4 kategorie informacji (150 rodzajów wskaźników), które publikowane są corocznie od 10 lat. Biblioteki mają obowiązek wypełniać ankiety, na podstawie których można wyliczyć 150 wskaźników $W$ celu dokonania porównań metod badawczych w Stanach Zjednoczonych i we Francji autor analizował metody i rodzaj zbieranych danych. Wnioski są następujące: kwestionariusze francuskie są bardziej szczegółowe od amerykańskich. Analiza danych udowodniła, że nie można ich porównać ze względu na różnice występujące między bibliotekami obu krajów. Biblioteki uczelni amerykańskich mają większe zbiory, inne żródła finansowania, funkcjonują w odmiennej organizacji systemu edukacji.

Doświadczenia bibliotekarzy słowackich dotyczące wdrażania norm jakościowych przedstawiła A. Kucianová ${ }^{91}$. Omawia ona zastosowanie norm międzynarodowej statystyki bibliotecznej oraz wskaźników działalności bibliotek przy ocenie bibliotek i systemów informacyjnych. Bibliotekarze słowaccy widzieli potrzebę badania jakości pracy biblioteki w następujących aspektach działalności: gromadzenie, udostępnianie zbiorów, budżet, formułowanie celu, alokacja zbiorów, jakość i czas udzielanej informacji. Normę STN ISO 11620 - Informacja i dokumentacja. Wskaźniki funkcjonalności bibliotek przetłumaczono na język słowacki, co świadczy, według autorki, o wadze tego problemu. Zaletami normy sa: ujednolicona terminologia, zwięzłe definicje wskaźników oceny funkcjonowania bibliotek, prosty sposób uzyskiwania i analizy danych otrzymanych z badań. Kucianová uważa, że błędem jest brak w omawianej normie wskaźników dotyczących: edukacji użytkowników, usług elektronicznych, propagowania działalności biblioteki, a także brak wskaźników pozwalających ocenić relacje społeczne biblioteki.

Od XIX w. czyni się starania ujednolicenia kryteriów precyzyjnego określania danych do statystyki bibliotecznej. Z analizy literatury wynika, że dane statystyczne, za pomoca których opisywano zasobność biblioteki, nie były jednoznaczne. Wielkość zbiorów tej samej biblioteki za określony rok różniła się w zależności od autora, który sporządzał zestawienie.

W Stanach Zjednoczonych od początku XX w. ukazywały się publikacje dotyczące jakości pracy bibliotek akademickich. Systematyczne publikowanie wyników działalności bibliotek pozwoliło na ocenę i porównywanie efektywności zarządzania w różnych placówkach. Obfita literatura pokazuje, że doświadczenia wynikające ze statystycznego opisu pracy przyczyniły się do upowszechniania wiedzy o narzędziach oceny pracy bibliotek akademickich. Prace przebiegały wielokierunkowo, dając rozmaite metody badań. Obok ewaluacji opartej na

${ }^{91}$ Kucianová A.: Uplatnienie noriem STN ISO 2789 a STN ISO 11620 pri kvantifikovani činnosti knižnic i informačných systémov. „Knižnica” 2004, nr 5, s. 220-226. 
opisie statystycznym podejmowano próby oceny usług bibliotecznych na podstawie subiektywnych opinii użytkowników. Bibliotekarze amerykańscy sami stworzyli standard oceny bibliotek akademickich oraz doprowadzili do uznania go przez komisje akredytacyjne.

Od początku XX w. wykorzystuje się do ewaluacji jedenaście zestawów pytań, ujmujących problemowo wszystkie funkcje biblioteki akademickiej ${ }^{92}$. Ewaluację przeprowadza się na potrzeby własne, instytucji macierzystej, oraz różnego rodzaju komisji akredytacyjnych. $W$ amerykańskich programach badawczych uczestniczą biblioteki z całego świata93. Różnorodność metod badawczych, precyzyjne definicje wszystkich elementów badań pozwalają na stwierdzenie, że bibliotekarze w Stanach Zjednoczonych przodują w światowych badaniach jakości pracy bibliotek akademickich.

Ważne prace dotyczące ewaluacji bibliotek akademickich ukazaly się również w Europie w latach siedemdziesiątych XX w. Prawdziwy jednak wzrost szacowania pracy bibliotek przy użyciu danych statystycznych i wskaźników funkcjonalności przypada na koniec $X X$ w., co jest skutkiem opublikowania i upowszechnienia norm dotyczących jakości pracy bibliotek ${ }^{94}$. Poza wskaźnikami oceniającymi efektywność zarządzania szczególną uwagę kładzie się na jakość usług bibliotecznych. Od początków XXI w. obok usług udostępnianych bezpośrednio coraz dokładniej bada się jakość usług realizowanych drogą elektroniczną ${ }^{95}$. Dzięki precyzyjnemu opisaniu i zdefiniowaniu wskaźników funkcjonalności w normach o charakterze międzynarodowym możliwa jest ewaluacja bibliotek oraz międzynarodowy benchmarking.

\section{Bibliografia}

1835 Balbi A.: Essai Statistique sur les Bibliotheques de Vienne. Vienne, Frederic Volke, 1835; Statistical Essay of the Libraries of Vienna and the World. Jefferson, North Carolina, McFarland 1986, przeł. Larry Barr i Janet L. Barr.

1906 Gerould J. T.: A plan for the compilation of comparative university and college library statistics. „The Library Journal” s. 761-763. [online]. [dostęp: 16.01.2008]. Dostępny w World Wide Web: <http://fisher.lib.virginia.edu/libsites/gerould/tgsartcl.html>

1911 Austen W.: Efficiency in College and University Library Work. „Library Journal”, nr 86, S. $566-569$

1923 Williamson C. C.: Training for Library Service. A Report Prepared for the Carnegie Corporation of New York, New York, Merrymount Press.

1932 Gerould J. T.: The College Library Building: Its Planning and Equipment. .New York. Scribners", s. 31.

1936 Rider F.: Library Cost Accounting. "The Library Quarterly”, nr 4, s. 331-381.

1946 Downs R. B.: Uniform Statistics for Library Holdings. „The Library Quarterly”, nr 16. s. 3-69.

${ }^{92}$ Podstawowe informacje o Standardzie ACRL daje: Encyclopedia of library and information science. Pod red Drake M. A., wyd. 2, Taylor \& Francis Group 2005, s. 299.

${ }^{93}$ LibQUAL, program, w którym od początku XXI w. uczestniczy ponad 1000 bibliotek z całego świata, więcej informacji dostępnych w: http://www.libqual.org/About/History/index.cfm

${ }_{94}$ ISO 11620:1998, 2008 Information and documentation. Library performance indicators, op. cit.; Poll R., Boekhorst P.: Measuring Quality;..., op.cit.

95 Ibidem. 
1953 Frarey C. J.: Studies of Use of the Subject Catalog: Summary and Evaluation. [W:] Subject Analysis of Library Materials. Pod red. M. F. Tauber, New York: Columbia University, School of Library Services, s. 147-166.

1956 Bush G. C., GALLIHER H. P., MORSE P. M.: Attendance and Use of the Science Library at MIT. „American Documentation”, s. 87-109.

1963 Piternick G.: Library growth and academic quality. "College and Research Libraries", nr 24, s. 223-329.

1965 Dunn O. C., Seibert W. F., Scheuneman J. A.: The Past and Likely Future of 58 Research Libraries, 1951-198. A Statistical Study of Growth and Change. University Libraries and Audio Visual Center, Purdue University, West Layfayette, Indiana.

1969 Fussler H. H., Simon L.: Patterns in the use of books in large research libraries. Chicago, The University of Chicago Press.

1970 Tagliacozzo R., Kochen M.: Information-Seeking Behavior of Catalog Users. „Information Storage and Retrieval", nr 6, s. 363-381.

1972 Evans E., Borko H., Ferguson P.: Review of criteria used to measure library effectiveness. „Bulletin of the Medical Library Association”, nr 1, 102-110. [online]. [dostęp: 06. 2007]. Dostępny w World Wide Web: <http://www.pubmedcentral.nih.gov/articlerender.fcgi?artid=198632>

1973 Orr R.: Measuring the goodness of library services: a general framework for considering. „Journal of Dokumentation” nr 29, s. 315-332.

1977 Broadus R. N.: The Application of Citation Analyses to Library Collection Building. „Advances in Librarianship", t. 7, s. 299-335.

Galvin, T. J., Kent, A.: Use of a University Library Collection: A Progress Report on a Pittsburgh Study. "Library Journal” nr 102, s. 2317-2320.

1978 Evans A., Mirsky P. S., Victoria M. J. de: Evaluation of a library program in a Carnegie model area health education center. „Bulletin Med. Library Assocation” nr 66, s. 190-199.

Katz F. M.: Directives pour évaluer un programme de formation des personnels de santé, Genčve, OMS.

1979 Schad J. G.: Pittsburgh university studies of collection usage: A symposium. „Journal of Academic Librarianship" nr 5, s. 60-70.

Kent A. i in.: Use of library materials. The University of Pittsburgh study. New York, Marcel Dekker Inc.

1982 Molyneux R. E.: An Examination of the Growth of Academic Libraries in the United States, 1972/73-1981/82. Unpublished dissertation, University of North Carolina, Chapel Hill.

1985 Kendon S.: Introduction, ARL Statistics, 1983-1984. Washington, Association of Research Libraries, s. 4-7; oraz tego samego autora: ARL Statistics, 1992-1996: A Guide to the Machine-Readable Version of the ARL Statistics. Washington, Association of Research Libraries 1996.

Sridhar M. S.: A case study of lent-out use of a special library. Library Science With a Slant to Documentation nr 22 s. 19-34

1987 Childers T. A., Van HOUSE N. A.: Labor Market Segmentation and Librarian Salaries. "The Library Quarterly" nr 2, s. 171-89.

House Van N. A. i in.: Output measures for public libraries. Chicago, Association of College and Research, Libraries, American library Association.

1988 Goodall D. L.: Performance measurement: A historical perspective. „Journal of Librarianship" 1988, nr 2, s. 128-144.

Klempin E.: Recommendation concerning the international standardization of library statistics der Unesco und die bibliotheksstatistischen Arbeit in der DDR. „Zentralbl. Bibl.-Wes", s. 49-55.

Powell, R. R.: The relationship of library user studies to performance measures. A review of the literature University of Illinois Graduate School of Library and Information Science Occasional Paper, nr 181. Champaign-Urbana, University of Illinois.

1989 Deccache A.: Pour mieux choisir son evaluation. Ličge, APES.

Bonn G. S.: Collection Analysis in Modern Librarianship. "Collection Management”, s. $73-91$. 
Sridhar M. S: Studies on use of library collections by scientists, engineers and technicians. „Aglis Journal”, nr 4, s. 9-17. [online]. [dostęp 16.03.2008]. Dostępny w World Wide Web: <http://eprints.rclis.org/archive/00012340/>

1990 Winkworth J.: Performance indicators for polytechnic libraries. „Library Review”, nr 5, s. $23-41$.

Lancaster W. F.: Evaluation as a management tool. „Public Library” nr 5, s. 289-294.

1991 Chacha R. N., Irving A.: An experiment in academic library performance measurement. „British Journal of Academic Librarianship”, nr 1, s. 16-26.

Childers T.: Measures of interlibrary reference. A manual. Sacramento, California State LibraryFoundation.

Baker S. L, Lancaster F. W.: The measurement and evaluation of library services. Wyd. 2, Arlington, Information Resources Press, [wyd. pierwsze1977].

Lithgow S. D., MacDougall A.: Performance assessment, today's confusion, tomorrow's solution? „IFLA Journal”, nr 4 , s. 371-378.

1992 Lofgren $\mathrm{H}$.: Priority and performance evaluation, a tool for libraries. „Australian Library Journal", nr 1, s. 14-30.

Stephen R.: Library use of performance indicators. „Library Revue”, nr 6, s. 22-36.

1993 Carbone P.: Survey of the Development of Library Performance Measures in France. "INSPEL", nr 3, s. 196-198.

Lancaster F. W.: If you want to evaluste your library. Wyd. 2, Champaign, University of Illinois, s. 76-85, [wyd. pierwsze 1988].

1995 Mike D., Revill D.: Towards the active collection: the use of circulation analyses in collection evaluatio. „Journal of Librarianship and Information Science”, nr 3, s. 149-157.

Shiao-Feng S., Lancaster F. W.: Evaluation of expert systems in reference service applications, "RQ”, vol. 35 , nr 2 , s. 219-228.

1996 Hernon P., Altman E.: Service quality in Academic Libraries. Greenwood Publishing Group. [online]. [dostęp: 14.05.2008]. Dostępny w World Wide Web: <http://books. google.pl/ books?id=3BXSV2Npt KQC\&pg =PA15\&source=gbs_toc_r \&cad $=0$ $0 \&$ sig $=$ Z_uKsu LPXFOI_UZKo jFnts1tQ_I>

Poll R., Boekhorst P.: Measuring Quality; Performance Measurement in Libraries. Munichen, K. G. Saur, seria: IFLA Publications, nr 76, Mierzenie jakości: międzynarodowe zalecenia do pomiaru wykonania zadań w bibliotekach akademickich. Tł. Bolesław Rek, Bibliothecalia Wratislaviensia 2004, nr 7, s. 16

1998 U. S. Bureau of Education: Public Libraries in the United States of America. Washington, Government Printing Office, 1876. [online]. [dostęp: 15.01.2008]. Dostępny w World Wide Web: <http://fisher.lib.virginia.edu/libsites/gerould/ tgsartcl.html>

1999 Cram, J.: Six impossible things before breakfast. A multidimensional approach to measuring the value of libraries. [W:] Proceedings of the 3rd Northumbria International Conference on Performance Measurement, „Libraries and Information Services”, Newcastle upon Tyne 2000, s. 19-29. [online]. [dostęp: 17.04.2007]. Dostępny w World Wide Web: <http://www.alia.org.au/-jcram/ six_things.html>

2000 Douglas R.: Performance measurement and performance indicators. A selective bibliography. [online]. [dostęp: 10.01.2008]. Dostępny w World Wide Web: <http://search-recherche.collectionscanada. ca/fed/searchResults.jsp? SourceQuery $=\&$ ResultCount $=5 \&$ PageNum $=1 \&$ MaxDocs $=-\&$ SortSpec $=$ score + desc $\&$ Language $=$ eng $\&$ Sources $=$ amicus $\&$ Sources $=$ mikan $\&$ Sources $=$ web $\&$ QueryText $=$ Bibliography + series+\%238>

Hennen T. J.: Why we should establish a national system of standards. „Amer. Library", nr 3, s. 43-45.

Kyrillidou M.: Research library trends: arl statistics. „Journal of Academic Librarianship", nr 6, s. 427-436; w wersji elektronicznej jako preprint Association of Research Libraries, Washington, DC 2002. [online]. [dostęp: 12.08.2009]. Dostępny w World Wide Web: <http://www.arl.org/bm doc/jal99.pdf>

Quinn B.: The McDonaldization of Academic Libraries? „College \& Research Libraries", nr 3, s. 248-261. [online]. [dostęp 14.05.2008]. Dostępny w World Wide Web: <http: //web2.ala. org/ala/acrl/acrlpubs/crljournal/ backissues2000b/may00/quinn. pdf> 
2001 Lamy J. P.: Évaluer un service de référence, quelques outils. „Bull. Bibl. France”, t. 46, nr 4 , s. 82-88.

Żbikowska-Migoń A.: Karl Heinrich Frömmichen (1736-1783) and Adrian Balbi (17821848). The pioneers of biblio- and scientometrics. "Scientometrics”, 2001, vol. 52, no. 2 , pp. 225-233.

2002 Briand B., Buffeteau A., Cudelou J.-F. i in.: Indicateur de performance des services documentaire, l'expérience d'un groupe de professionnels de l'information. „Documentaliste" nr 1-2, s. 26-33.

Hernon P.: Quality: New directions in the research. „Journal of Academic Librarianship" nr 28, s. 224-231.

Hernon P., Dugan R. E.: An action plan for outcomes assessment in your library. Chicago, American Library Association.

Spohrer J. H.: Les bibliothéques universitaires françaises et nord-américaines, prolégomčnes r une étude comparative. „Bull. Bibl. France”, nr 5, s. 32-35.

2003 Durrance J. C., Fisher K. E.: Determining how libraries and librarians help. „Library Trends" nr 51, s. 305-334. [online]. [dostęp: 15.04.2007]. Dostępny w World Wide Web: <http://www.ischool.washington. edu/fisher/pubs/library. trends.2003.pdf>

Poll R.: Impact/outcome measures for libraries. „Liber Quarterly", nr 13, nr 3/4, s. 329-342. [online]. Dostępny World Wide Web: <http://liber.library.uu.nl/>

Reichmann G.: Size matters, Einfluss der Bibliotheksgrösse auf Bibliothekskennzahlen am Beispiel von Fachhochschulbibliotheken. „Buch und Bibl.” nr 55 , s. 235-239.

2004 Fett O. F.: Impact - Outcome - Benefit. Ein Literaturbericht zur Wirkungsmessung für Hochschulbibliotheken. Berlin. [online]. Dostępny w World Wide Web: <http:// www.ib.hu-berlin.de/ kumlau/handreichungen/h142>

Hernon P., Dugan R. E.: Different perspectives on assessment and evaluation: The need to refine and link them. „Proceedings of the 5th Northumbria International Conference on Performance Measurement in Libraries and Information Services 2003", Northumbria University, s. 23-30. [online]. Dostępny w World Wide Web: <http:// www. emeraldinsight.com/Inight/viewContentltem.do;jsessionid=782B6DC4437CCB0D BF CC1DD9 2F8C270B? contentTyp =Article\&hdAction=Inkhtml\&contentld $=158194$ 9\&d Type $=$ SUB\&history $>$

Fisher K. E.: LIS 579: Outcome evaluation. The Information School of the University of, Washington, dostIBEC. [online]. [dostęp: 15.08.2008]. Dostępny w World Wide Web: <http://ibec.ischool. washington. edu/ default 1024. aspx?cat=Home\&b=y> Kucianová A.: Uplatnienie noriem STN ISO 2789 a STN ISO 11620 prikvantifikovani činnosti knižnic i informačných systémov. „Knižnica” nr 5, s. 220-226.

Brophy P.: Narrative-based librarianship. [W:] The area of information and social communication. Festschrift for Professor Wanda Pindlova, „Studies in Library and Information Science", vol. 10, Krakow, Jagiellonian University Press 2004, s. 188-195. [online]. [dostęp:10.01.2007]. Dostępny w World Wide Web: <http://www.cerlim.ac.uk/ projects/nbl_brophy.pdf.>

2005 Poll R.: Kann man die „Wirkung” von Bibliotheken messen? Internationale Projekte zu "impact" und "outcome" in öffentlichen und wissenschaftlichen Bibliotheken. "Zeitschrift für Bibliothekswesen und Bibliographie"s. 357-369;

Durrance J. C., Fisher K. E., Hinton M. B.: How Libraries and Librarians Help. A Guide to Identifying User-Centered Outcomes. Chicago, American Library Association. Poll R.: Was dabei herauskommt: Wirkungsforschung für Bibliotheken. "Zeitschrift für Bibliothekswesen und Bibliographie" nr 2-3, s. 59-70.

2006 Éléments méthodologiques d'évaluation de l'activité de documentation dans les comités d'éducation pour la santé, [online]. [dostęp: 16.05.2008]. Dostępny w World Wide Web: <http://craes-crips.com/pub/fixes/ 21_elements_devaluation_activite_doc_2006.pdf>

Poll R., Payne P.: Impact measures for libraries and information services. „Library Hi Tech", nr 24/4, s. 547-562. [online]. [dostęp: 04.2007]. Dostępny w World Wide Web: <http://conference.ub.uni-bielefeld.de/2006/proceedings/payn_poll_final_web.pdf>. 
Xalter S.: Der „Bibliotheksindex" (BIX) für wissenschaftliche Bibliotheken-eine kritische Auseinandersetzung. BIX - Bibliotheksindex. [online]. [dostęp: 20.08.2007]. Dostępny w World Wide Web: <http://w210.ub.unituebingen.de/dbt/volltexte/2006/ 2440/pdf/B|X_OPUS_Tue Xalter.pdf.>

2007 Poll R., Boekhorst P.: Measuring Quality.; Performance Measurement in Libraries. Wyd. 2, Munich, K. G. Saur, seria: IFLAPublications, nr 127.

2008 ISO 11620:2008 Information and documentation. Library performance indicators. Molyneux R. E.: The Gerould Statistics, 1907/1908-1961/1962, second edition, An historical compilation of data from academic libraries in the United States and Canada. [online]. [dostęp: 15.02.2008]. Dostępny w World Wide Web: <http:// fisher.lib.virginia.edu/libsites/gerould/index.html\#toc>

\section{Summary}

The article presents history of selected methods of academic libraries evaluation, from the 1st part of the 18th century up till 2008. The author refers to publications being often cited in specialized bibliographies, as essential for this topic. Literature analysis was done to select the most important research topics in a historical aspect. Development of quantitative surveys in the United States, and their influence on the European countries was discussed. 